\title{
2006-43: DEVELOPING A DESIGN BASED ALTERNATIVE ENERGY COURSE
}

\section{Craig Somerton, Michigan State University}

CRAIG W. SOMERTON Craig W. Somerton is an Associate Professor of Mechanical

Engineering and Associate Chair of Mechanical Engineering at Michigan State University. He teaches in the area of thermal engineering including thermodynamics, heat transfer, and thermal design. Dr. Somerton has research interests in computer design of thermal systems, transport phenomena in porous media, and application of continuous quality improvement principles to engineering education. He received his B.S. in 1976, his M.S. in 1979, and his Ph.D. in 1982, all in engineering from UCLA.

\section{Andre Benard, Michigan State University}

ANDRE BÉNARD Andre Bénard is an Associate Professor of Mechanical Engineering at Michigan State University. He teaches in the area of thermal engineering and numerical methods. Dr. Bénard has research interests in transport phenomena in materials processing, heat transfer, polymers and composites microstructures, multiphase problems, finite elements. He received his B.S. in 1988 from the University of Sherbrooke, his M.S. in 1991 from the Ecole Polytechnique de Montréal, and his Ph.D. in 1982 from the University of Delaware, all in engineering. 


\section{Developing a Design Based Alternative Energy Course}

\section{$\underline{\text { Introduction }}$}

With the rising cost of oil, the depletion of domestic natural gas supplies, and the documented impact of increased $\mathrm{CO}_{2}$ production on global warming, engineering students have developed a renewed interest in alternative energy technologies and careers. This renewed interest, coupled with the initiation of state and federal sponsored programs to enhance alterative energy education such as the Michigan NextEnergy program, has led to the establishment of a design based alternative energy course in the mechanical engineering department at Michigan State University. This paper presents the development of the course, its evolution through two offerings of the course, feedback from the students, and lessons learned by the instructors.

\section{Development of the Course}

For several years one of the authors has taught a traditional thermal design course which focuses on conventional energy sources and systems (ME 416 Computer Assisted Design of Thermal Systems). It is a design intensive course that significantly utilizes projects to facilitate the students' learning. It has become a very successful course with one of the largest enrollments for an elective course in the mechanical engineering program. The authors decided to use this learning model for a new course in alternative energy systems with an emphasis on design.

A new course with a design emphasis was welcome, as the mechanical engineering curriculum at Michigan State University needed an additional design-based technical elective course. A design intensive technical elective is intended to provide students with additional experience in the analytical design component of the design process. The need for a design elective set the framework for a course in alternative energy, namely, one that focused on the use of mathematical models to predict performance and to design such systems.

With the course model decided, the authors had to decide between covering a single alternative energy system, such as solar or wind power systems or fuel cells (most appropriate for the state of Michigan), or attempt to cover several forms of alternative energy. In discussions with colleagues working in the alternative energy discipline, it became clear that the best strategy would be to cover many alternative energy sources. Furthermore, it was decided to broaden the notion of alternative energy so as to only exclude energy systems based on coal or petroleum. With this background, the following definition of alterative energy was developed:

Alternative energy is an energy that is not currently being fully utilized by human beings, but may replace conventional energy sources.

At this point in time a proposal was developed for consideration by the mechanical engineering undergraduate curriculum committee. It is provided as Attachment 1 and includes a course description, course goals, and detailed course learning objectives. The committee approved this proposal and the course was offered for the first time under a temporary number, ME 491 Selected Topics. This is the normal procedure for a new course, since the faculty will only 
approve a new course as a permanent course if it has been taught once under the temporary number.

With regards to the logistics of teaching the course, the authors decided to share the teaching load. For its first offering, the course would be team-taught, each author presenting about half the lectures and supervising half the projects. In future offerings, only one author would teach the course, but it would alternate every year between the two authors. The syllabus for the first year offering (spring 2004) is shown in Attachment 2. The initials following a topic or project indicate which author took primary responsibility for it. This approach proved to be a very efficient way to develop course materials.

In developing the lectures and projects for the course, it occurred to the authors that in the field of alternative energy, the practicing engineer must have an understanding of the political, social, and economic issues associated with alternative energy. These topics were added to the course and are reflected in the syllabus, both in lecture topics and project assignments.

\section{Evolution of the Course}

At the time of submission of this paper, the course has been taught twice (spring 2004 and spring 2005). As noted above, the spring 2004 course was team-taught by the two authors, while the spring 2005 course was taught by just one of the authors (CWS). In reviewing the successes and failures of the first offering of the course, the authors incorporated three modifications into the second offering of the course. First, the topics of the course were rearranged. This was primarily done so that the typical thermal/fluids sequence was reflected. That is, starting with fuel cells, which is primarily thermodynamics based, moving on to ocean and wind energy (primarily fluid mechanics based), and concluding with geothermal, solar and nuclear energy (primarily heat transfer based) allowed the course to align with these technical topics as they are presented in the mechanical engineering curriculum at Michigan State University. Further, since the co-requisite for the course is the required heat transfer course, the topics that require heat transfer are covered in the later stages of the course. The reordering of topics between the two offerings is shown in Table 1.

The second modification deals with the type of assignments. In the spring 2004 offering the only graded assignments were the six projects and this led to a lack of attendance at the lectures. In order to motivate the students to attend lecture, the spring 2005 offering included three quizzes, with a reduction in the number of projects to four. The third modification also involved the assignments. In order to bring closure to the course, a final assignment was added. Each student was asked to identify an alternative energy issue and draft a one page recommendation on the issue that they would submit as an advisor to the Secretary of Energy to implement their recommendation. During the final exam period for the class, the students made a 1 minute presentation on the recommendation and defended their recommendation during a 2 minute question period with the class and instructor. A summary of the assignments for each course offering is given in Table 2 . 
Table 1 Comparison in Topics between the Two Course Offerings

\begin{tabular}{|l|l|c|}
\hline Spring 2004 & Spring 2005 & $\begin{array}{c}\text { Number } \\
\text { of Weeks }\end{array}$ \\
\hline \hline $\begin{array}{l}\text { Sociological, Political, } \\
\text { and Economic Aspects }\end{array}$ & $\begin{array}{l}\text { Sociological, Political, } \\
\text { and Economic Aspects }\end{array}$ & 1 \\
\hline $\begin{array}{l}\text { Review of Basic Thermal } \\
\text { Sciences }\end{array}$ & $\begin{array}{l}\text { Review of Basic Thermal } \\
\text { Sciences }\end{array}$ & 1 \\
\hline Fuel Cells & Fuel Cells & 2 \\
\hline Wind Energy & Ocean Energy & 2 \\
\hline Geothermal Energy & Wind Energy & 2 \\
\hline Ocean Energy & Geothermal Energy & 2 \\
\hline Nuclear Energy & Solar Energy & 2 \\
\hline Solar Energy & Nuclear Energy & 2 \\
\hline Biomass Energy & Biomass Energy & 1 \\
\hline
\end{tabular}

\section{Lectures}

A standard approach has been used to cover each of the alternative energy technologies in lecture. An alternative energy is introduced to the class through an active learning experience in which the students identify the advantages and disadvantages of the technology. This activity immediately engages the students and provides the instructor with feedback on the knowledge the class has concerning the technology. Energetic issues of the power source are presented. Such as the source of wind energy or the use of $\mathrm{E}=\mathrm{mc}^{2}$ for nuclear energy. Following this a power point presentation is made that shows the students the various technologies that are used to harness the energy source. Finally, predictive models for these technologies are presented and some simple examples are worked. This approach does an excellent job of addressing the learning objectives for each energy source. The power point presentations and the predictive models presented may be found at the course's web site:

$$
\text { http://www.egr.msu.edu/ somerton/AEnergy/ }
$$

For ocean energy the following learning objectives have been set:

a. Students are able to understand the nature of the ocean as an energy source

b. Students are able to understand and evaluate different types of ocean energy sources, such as ocean thermal energy conversion, wave energy, and tidal energy

c. Students are able to calculate the performance of ocean power systems

d. Students are able to design an ocean power system

Objective (a) is addressed through the advantage/disadvantage active learning exercise, as well as the lecture presentation on the nature of the energy source. Objective (b) is addressed through the power point presentation. The lecture on predictive models and the working of examples address objectives (c) and (d). The projects and quizzes are used to further reinforce the learning of objectives (c) and (d). 
Table 2 Course Assignments

\begin{tabular}{|c|l|l|}
\hline & Spring 2004 & Spring 2005 \\
\hline \hline Projects & 1. Politics/Economics of & 1. Politics/Economics of \\
& Conversion to Alternative & Conversion to Alternative \\
& Energy & Energy \\
& 2. Design of a Fuel Cell System & 2. Design of a Fuel Cell System \\
& $\begin{array}{c}\text { 3. Design of a Wind Farm } \\
\text { 4. Design of a Geothermal System }\end{array}$ & $\begin{array}{l}\text { 3. Design of a Wind Farm } \\
\text { 4. Design of a Solar Energy } \\
\text { System }\end{array}$ \\
& $\begin{array}{c}\text { 5. Design of a Wave Energy } \\
\text { System }\end{array}$ & \\
& $\begin{array}{c}\text { 6. Design of a Solar Energy } \\
\text { System }\end{array}$ & \\
\hline Quizzes & None & 1. Fuel Cell Calculations \\
& & 2. Wind Turbine Cost Calculation \\
& & 3. Solar Collector Calculations \\
\hline Presentations & None & Policy Recommendation \\
\hline Grade & 1/6 each project & 5\% each quiz, 20\% each project, \\
Weighting & & \multicolumn{2}{|l}{} \\
\hline
\end{tabular}

The quizzes that were introduced during the course's second offering focused on the lecture material. To prepare students for the quizzes, practice problems have been developed that use the predictive models taught in class. These quizzes and practice problems (with their solutions) may be accessed at:

$$
\text { http://www.egr.msu.edu/ somerton/AEnergy/ }
$$

\section{Projects}

One of the biggest challenges in teaching a design based course is the development of projects. The projects need to be rigorous, interesting, realistic, and use modern engineering tools. Hence, one would like to have computer models for the students to use. There appears to be three sources for such software and the authors have used all three in the teaching of this course. First, the students could be asked to develop their own computer programs. For the fuel cell project of spring 2005, the students were asked to develop Excel spreadsheets for two different fueled fuel cells that will perform performance calculations. Further the students were then to demonstrate the spreadsheets through the development of performance characteristics for the fuel cells. The difficulty with this approach is that often the software development becomes the focus of the project rather than the design analysis. A second approach is to use commercial software. Software such as ASPEN could be used, but it requires a significant investment in funds for a site license and a significant investment in time to become competent with it. An alternative the authors have discovered is web based software. Two sites that the authors have found to be very useful are: 


\section{RETScreen International: http://www.retscreen.net/ \\ Iowa Energy Center, Wind Turbine Output Calculator: \\ http://www.energy.iastate.edu/renewable/wind/assesment/}

During the spring of 2005, the students were assigned a project using the Wind Turbine Output Calculator. They were asked to conduct an economically based design analysis for two different size wind turbines at two different sites in Iowa. The calculator provides the energy produced, while the students must set up their own spreadsheet to do the economic analysis. Spreadsheets from the RETScreen web site were used for both solar design projects and underground heat pump (geothermal) design projects.

The third approach to providing calculation tools for the project is to develop the software inhouse. Though often faculty find it difficult to find the time to do this, undergraduate students doing an independent study project can often be utilized to develop these programs. Using this approach, three such software packages have been developed to assist in the design of wind turbines, wave oscillating water columns, and ocean current turbines.

We now focus on two of the projects used in this course. The first is a wind power system design that uses web based software. The project write-up is provided as Attachment 3 . It requires the team to undertake a design study to determine the turbine type and the optimal tower height for two sites in Iowa. The calculation tool used is the web based Wind Turbine Output Calculator provided by the Iowa Energy Center. This calculator will determine the operating conditions, including the estimated energy output for a specific location and specified turbine type. An example of this output is shown in Table 3. Using these results an objective function of the predicted cost of the electricity in $\$ / \mathrm{kW} \cdot \mathrm{hr}$ is developed with a student generated spreadsheet. It is suggested to the students that graphs of power cost versus tower height for all six turbines at both sites will be helpful in making the design decisions. The students are provided with a grading sheet that provides them with an explicit statement of the requirements and expectations.

The second project involves a wave power system using an oscillating water column. An inhouse MATLAB program is used, which allows the students to investigate the design at five different sites and with different heights and diameters. The user may choose any month for the study. Typically results from the program are shown in Table 4. These results, along with cost data provided by the instructor will allow the student to calculate the predicted cost of the electricity in $\$ / \mathrm{kW} \cdot \mathrm{hr}$, under the constraint that the system power output will be $10 \mathrm{~kW}$. This will then allow the team to choose an optimal height and diameter for the chamber. The team compares the results of the design studies at the different sites. The design team also performs a design study for each of four different months at each site. 
Table 3 Results from Wind Turbine Output Calculator

\begin{tabular}{|c|c|c|c|c|c|}
\hline & \begin{tabular}{|l|} 
Average \\
Speed (mph)
\end{tabular} & $\mid \begin{array}{l}\text { Air } \\
\text { Density }\end{array}$ & $\begin{array}{l}\text { Average Wind } \\
\text { Power Density }\left(\mathrm{W} / \mathrm{m}^{2}\right)\end{array}$ & \begin{tabular}{|l|} 
Capacity \\
Factor $(\%)$
\end{tabular} & $\begin{array}{l}\text { Estimated Output } \\
\text { for Period (kWh) }\end{array}$ \\
\hline Annual & 14.69 & 1.220 & 287 & 25.20 & $1,662,048$ \\
\hline Jan & 15.43 & 1.283 & 321 & 29.05 & 154,710 \\
\hline Feb & 15.2 & 1.278 & 323 & 28.35 & 136,947 \\
\hline Mar & 16.32 & 1.244 & 370 & 32.04 & 176,082 \\
\hline Apr & 16.48 & 1.217 & 397 & 32.21 & 174,994 \\
\hline May & 14.49 & 1.190 & 266 & 23.73 & 136,288 \\
\hline \begin{tabular}{|l|} 
June \\
\end{tabular} & 13.5 & 1.171 & 211 & 19.50 & 110,133 \\
\hline July & 12.47 & 1.161 & 156 & 14.86 & 87,547 \\
\hline Aug & 12.34 & "1.164 & 148 & $\begin{array}{l}14.14 \\
\end{array}$ & 83,046 \\
\hline Sep & 13.21 & 1.178 & 188 & 17.86 & 100,324 \\
\hline Oct & 14.22 & 1.211 & 238 & 22.34 & 126,129 \\
\hline Nov & 15.11 & 1.246 & 324 & 27.58 & 146,388 \\
\hline Dec & 15.16 & 1.279 & 323 & 28.24 & 150,941 \\
\hline
\end{tabular}

City: Ackworth Turbine: Zond 750-50 Tower Height: 165 feet

Table 4 Results from Oscillating Water Column Program

$\begin{array}{lc}\text { Chamber Height: } & 5.00 \mathrm{~m} \\ \text { Chamber Diameter: } & 0.30 \mathrm{~m} \\ \text { Height of Wave: } & 3.90 \mathrm{~m} \\ \text { Frequency of Wave: } & 0.10 \mathrm{~Hz} \\ \text { Thickness of Wave: } & 1.00 \mathrm{~m} \\ \text { Initial Temperature: } & 279.95 \mathrm{~K} \\ \text { Initial Pressure: } & 101.00 \mathrm{kPa} \\ \text { Initial Mass: } & 0.44 \mathrm{~kg} \\ \text { Initial Volume: } & 0.35 \mathrm{~m}^{\wedge} 3 \\ \text { Final Temperature: } & 512.84 \mathrm{~K} \\ \text { Final Pressure: } & 841.26 \mathrm{~K} \\ \text { Final Volume: } & 0.08 \mathrm{~K} \\ \text { Final Mass: } & 0.44 \mathrm{~kg} \\ \text { Exit Temperature: } & 255.29 \mathrm{~K} \\ \text { Turbine Work: } & 0.02 \mathrm{~kJ} \\ \text { OWC Power Output: } & 0.00 \mathrm{~kW} \\ \text { Wave Power: } & 2.23 \mathrm{~kW} \\ \text { OWC Efficiency: } & 0.17 \%\end{array}$


A summary of the projects used in the class is for the first two offerings is provided below. All project materials may be found at the course web site:

$$
\text { http://www.egr.msu.edu/ somerton/AEnergy/ }
$$

Project: Politics/Economics of Conversion to Alternative Energy

Semester: Spring 2004, Spring 2005

Summary: Identify a municipality with which the student is familiar and develop a proposal for the conversion to an alternative/renewable energy. The proposal should include:

- a current assessment of the energy consumption for the municipality

- an assessment of the political/societal energy issues for the municipality

- an evaluation of the possible alternative/renewable energy sources for the municipality

- an implementation recommendation

- a public statement in favor of the implementation

- a public statement in opposition to the implementation

Calculation Tools: Various web sites found by the students. It was suggested that the students begin with the Energy Information Administration site (www.eia.doe.gov)

Project: Design of a Fuel Cell System

Semester: Spring 2004

Summary: Provide an analysis of possible fuel cell systems that could be used for transit buses, considering two possible fuels: hydrogen and methanol. The project should include:

- selection of the fuel cell systems that can accommodate these fuels

- informing city regulators, the transportation authority and the community about the operation of fuel cell systems and their performance (sustained by basic calculations)

- determining the critical technical, environmental, economic (opportunities for local businesses), and social factors that need consideration in the introduction of fuel cell buses

- recommending a type of fuel and a fuel cell system for the transit buses based on your preliminary analysis

Calculation Tools: Various web sites found by the students. It was suggested that the students begin with the Energy DOE web site (www.fuelcells.org)

Project: Design of a Fuel Cell System

Semester: Spring 2005

Summary: Develop Excel spreadsheets for two different fueled (hydrogen and methanol or ethanol) fuel cells that will perform performance calculations. Demonstrate the spreadsheets through the development of performance characteristics for the fuel cells.

Calculation Tools: Excel spreadsheet developed by the students 
Project: Design of a Wind Farm

Semester: Spring 2004

Summary: Provide a preliminary design for a wind farm in the state of Utah by investigating two different sites in the state, each with a different wind power class. For each site (and wind power class), the design team will undertake a design study to determine

- the optimal blade length

- the optimal rotor height

- the optimal blade material

The objective function used in the design study will be the predicted cost of the electricity in $\$ / \mathrm{kW} \cdot \mathrm{hr}$. The team will want to compare the results of the design studies at the two sites.

Calculation Tools: An in-house MATLAB computer program, WindPower.p, that performs the operational and economic analysis for three different wind turbine rotors was provided to assist in the calculations.

Project: Design of a Wind Farm

Semester: Spring 2005

Summary: Provide preliminary designs for wind power systems for two different sites in the state of Iowa. The two sites are to be in different counties in the state of Iowa. A design analysis should be done at each site for two power systems. One system should have a operating of power $1500 \mathrm{~kW}$, while the other system should have an operating power of $65 \mathrm{~kW}$. For each site and power system, the design team will undertake a design study to determine

- turbine type

- the optimal tower height

The following turbines shall be considered for the two power systems:

$1500 \mathrm{~kW}$ Power System

Nordtank 1500/64 (rotor diameter of $60 \mathrm{~m}$ )

GE Wind $1.5 \mathrm{~s}$ (rotor diameter of $77 \mathrm{~m}$ )

NEG Micon NM72C/1500 (rotor diameter of $82 \mathrm{~m}$ )

$65 \mathrm{~kW}$ Power System

Vestas V15 $65 \mathrm{~kW}$ (rotor diameter of $18 \mathrm{~m}$ )

Nordtank 65 (rotor diameter of $20 \mathrm{~m}$ )

Windmatic $15 \mathrm{~S}$ (rotor diameter of $11 \mathrm{~m}$ )

The objective function used in the design study will be the predicted cost of the electricity in $\$ / \mathrm{kW} \cdot \mathrm{hr}$. The team will want to compare the results of the design studies at the two sites.

Calculation Tools: Iowa Energy Center Wind Turbine Output Calculator (http://www.energy.iastate.edu/renewable/wind/assesment/) and student developed spreadsheet for the economic analysis. 
Project: Design of a Geothermal System

Semester: Spring 2004

Summary: Identify a locality and provide a proposal on the advantages or disadvantages of using ground based heat pumps for upscale new housing developments. Also provide the same information for a commercial building. Carry out the following tasks:

- To provide a current assessment of the technology

- To provide an assessment of the impact on the local businesses

- To determine the critical technical, environmental, economic (opportunities for local businesses), and social factors that need consideration if such systems were mandated by the municipality

- To provide a summary of the energy savings and a financial summary

Calculation Tools: Excel spreadsheets from the RETScreen International site (www.retscreen.net/ang/menu.php)

Project: Design of a Wave Energy System

Semester: Spring 2004

Summary: Provide a preliminary design for an oscillating water column system power within the territory of the United States for two different sites. The following sites have been targeted for this study.



For each site, the design team will undertake a design study to determine

- the optimal chamber height (within $0.5 \mathrm{~m}$ )

- the optimal chamber diameter (within $0.5 \mathrm{~m}$ )

The objective function used in the design study will be the predicted cost of the electricity in $\$ / \mathrm{kW} \cdot \mathrm{hr}$, under the constraint that the system power output will be $10 \mathrm{~kW}$. The team will want to compare the results of the design studies at the different sites. The design team should perform a design study for each of four different months at each site.

Calculation Tools: An in-house MATLAB computer program, OWCPower.p, that performs the operational and economic analysis for an oscillating water column power system at five different locations was provided to assist in the calculations. 
Project: Design of a Solar Energy System

Semester: Spring 2005

Summary: Provide preliminary designs for solar electric and solar hot water heating for the cabins. Consider a variety of different cabin ranging from very rustic to very upscale.

Photovoltaics are to be used to provide the electricity for the cabins. As a modeling convenience the electric load will be modeled by 100 watt, AC light bulbs, over the range of 2 to 15 light bulbs operating 4 hours a day. The design team is to consider two PV modules:

a-Si at a cost of $\$ 4500$ per $\mathrm{kW}$

poly-Si at a cost to be determined by the team

For the poly-Si PV module, the team is to determine the unit cost that will make such a system equivalent in cost to the a-Si system with a load of 10 light bulbs. A flat plate solar collector is to be used to provide the hot water for the cabins that will be used for both space heating and domestic hot water. As a modeling convenience the heating load will be modeled by a hot water flow rate of liters/day at $60^{\circ} \mathrm{C}$, over the range of 600 to 3000 liters/day. The design team is to consider two flat plate collector systems:

Unglazed at a cost of $\$ 50$ per square meter

Evacuated at a cost to be determined by the team

For the evacuated collector system, the team is to determine the unit cost that will make such a system equivalent in cost to the unglazed system with a load of 2000 liters/day.

Calculation Tools: Excel spreadsheets from the RETScreen International site (www.retscreen.net/ang/menu.php)

\section{Student Feedback}

The student reaction to the new course has been quite positive with an enrollment averaging nearly 40 . It is interesting to note that the enrollment of women in the class is $25 \%$, which is nearly 10 points above the department percentage. The students in the spring 2005 course were surveyed with the instrument shown in Figure 1. This survey was conducted via email during the summer following the course. The results are shown in Fig. 2. The students' perception of their learning is quite strong. They were very much in favor of having one course to cover several alternative energy sources by an $82 \%$ to $18 \%$ margin. The results also show that students' believe that their learning is enhanced for the topics on which they had project assignments.

\section{Lessons Learned}

- Student attendance at lecture is a problem, not completely solved with the addition of quizzes.

- The class attracts a high percentage of women students (about twice the percentage as woman in the mechanical engineering program). The reasons for this are not clear, but may fall along the same lines as the reasons for large percentages of woman in biomedical engineering.

- Students are not as skilled in negotiating the web as faculty may think. Often, they require some starting points.

- As is well known, projects enhance students' learning.

- Students enjoyed the blending of the socio-political aspects of alternative energy with the technical aspects. 
- The use of design projects in covering several alternative energy technologies provide the students with both breadth and some depth. Though the depth is not what one could achieve with a course on a single alternative energy.

- Following the course, several students approach the faculty concerning careers in alternative energy. Unfortunately, the faculty members were able to give little guidance, except to direct the students to large energy companies (formerly known as oil companies).

- Team teaching during the development phase of the course proved most effective. For the second and third teaching of the course (done by an individual and not the team) the preparation time required was greatly reduced. 


\section{Figure 1 Student Feedback Survey}

Please provide a response to the questions below using a 5, 4, 3, 2, 1 scale with 5 being excellent, 3 being adequate and 1 being poor.

1. What is your level of awareness concerning the socio-political aspects of alternative energy systems?

2. What is your level of awareness concerning the economic aspects of alternative energy systems?

Again using the 5, 4, 3, 2, 1 scale, evaluate your understanding of the technical aspects of the following advanced energy technologies.

3. Solar Energy:

4. Geothermal Energy:

5. Wind Energy:

6. Fuel Cells:

7. Ocean Energy:

8. Biomass Energy

9. Nuclear Energy:

10. Would you have preferred to take a single course that would go into more depth on a single alternative energy technology, such as fuel cells or wind energy, instead of this course that broadly treated several alternative energy technologies?

(Yes or No) 
Figure 2 Results of Student Feedback Survey

1. What is your level of awareness concerning the socio-political aspects of alternative energy systems? Average: 4.05

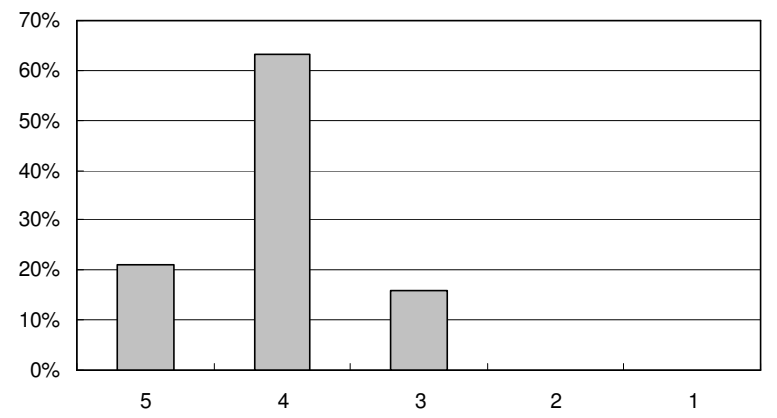

2. What is your level of awareness concerning the economic aspects of alternative energy systems? Average: 4.11

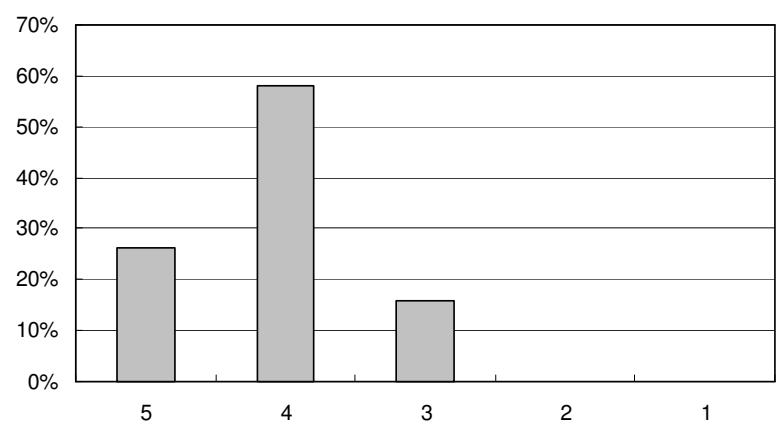

3. Solar Energy: Average: 4.00

5. Wind Energy: Average: 4.05

7. Ocean Energy: Average: 3.21

9. Nuclear Energy: Average: 3.16
4. Geothermal Energy: Average: 3.44

6. Fuel Cells: Average: 3.67

8. Biomass Energy: Average: 3.16

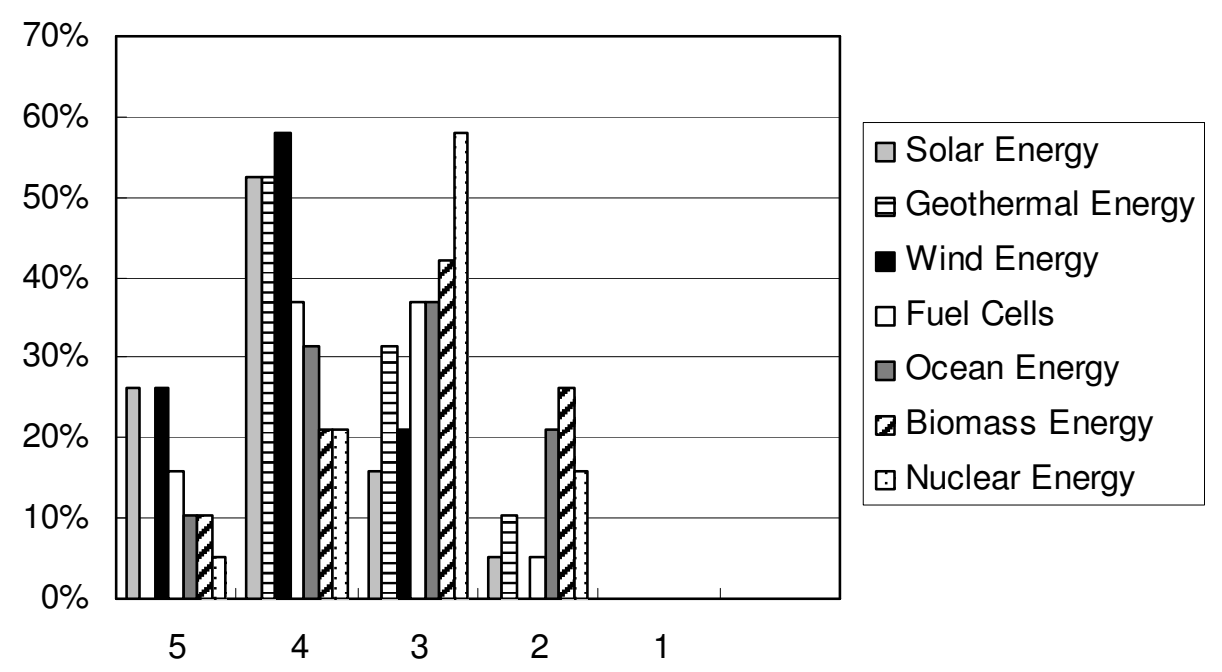




\section{Attachment 1 Course Proposal \\ ME 417 \\ Design of Alternative Energy Systems}

\section{Course Description}

Several different alternative energy systems, including ocean, wind, fuel cells, solar, and nuclear, will be analyzed. Predictive models for the systems will be used in design studies. Pre-requisite: ME 410 or concurrently

\section{Course Goals}

1. Development and practice of design skills as they apply to alternative energy systems.

2. Development of modeling skills.

3. Development and refinement of computer skills

\section{Course Learning Objectives}

\section{Concepts of Analytical Design}

a. Students recognize the value of using predictive models in the design process

b. Students are able to conduct parametric studies

c. Students are able to determine an appropriate objective or cost function

d. Students are able to perform a simple optimization

\section{Wind Power Systems}

a. Students are able to understand the nature of wind as an energy source

b. Students are able to understand and evaluate different types of wind turbines

c. Students are able to calculate the performance of wind turbines

d. Students are able to design a wind power system

\section{Ocean Power Systems}

a. Students are able to understand the nature of the ocean as an energy source

b. Students are able to understand and evaluate different types of ocean energy sources, such as ocean thermal energy conversion, wave energy, and tidal energy

c. Students are able to calculate the performance of ocean power systems

d. Students are able to design an ocean power system 


\section{Attachment 1 Course Proposal (continued)}

\section{Solar Energy Systems}

a. Students are able to understand the nature of the sun as an energy source

b. Students are able to understand and evaluate different uses of solar energy, such as direct conversion to electricity (photovoltaic), active space heating, and passive heating and cooling

c. Students are able to calculate the performance of solar energy systems

d. Students are able to design a solar energy system

\section{Nuclear Power Systems}

a. Students are able to understand the nature of nuclear fission and fusion as energy sources

b. Students are able to understand and evaluate different types of nuclear power systems

c. Students are able to calculate the performance of fission based nuclear power systems

d. Students are able to design a fission based nuclear power system

\section{$\underline{\text { 6. Fuel Cells }}$}

a. Students are able to understand the nature of the fuel cells as an energy source

b. Students are able to understand and evaluate different type of fuel cells

c. Students are able to calculate the performance of fuel cells

d. Students are able to design a fuel cell energy system

\section{Hybrid Electric Propulsion Systems}

a. Students are able to understand the nature of the hybrid electric propulsion systems

b. Students are able to understand and evaluate different types of hybrid electric propulsion systems

c. Students are able to calculate the performance of hybrid electric propulsion systems

d. Students are able to design a hybrid electric propulsion system

\section{$\underline{\text { 8. Computer Skills }}$}

a. Students are able to write programs in MATLAB

b. Students are be able to program in Excel

c. Students are able to use the Solver function in Excel

d. Students are able to graph in Excel

\section{Engineering Project Skills}

a. Students are able to communicate ideas, methods, results, and decisions effectively in a written technical memo

b. Students are able to work effectively with a partner to equitably distribute and carry out the tasks associated with a design project.

c. Students are able to evaluate their performance on a project team 
Attachment 2 Syllabus for Spring 2004

ME 417

(ME 491 sec. 602)

Design of Alternative Energy Systems

MWF 9:10-10:00, 1257 Anthony Hall

Professor Craig W. Somerton

2439 Engineering Building

Hours: MWF 10:30-11:30

353-6733

somerton@egr.msu.edu
Instructors

Professor André Bénard

2425 Engineering Building

Office Hours: MW 10-11:30

432-1522

benard@egr.msu.edu

course web page: http://www.egr.msu.edu/classes/me491-602/

\section{Tentative Course Outline}

(Since this is a new course, the schedule outlined below may change as the semester proceeds)

$\begin{array}{lll}\begin{array}{ll}\text { Week of } \\ 1 / 12\end{array} & & \text { Topics } \\ 1 / 19 & & \text { Sociological, Political and Economic Aspects (CWS) } \\ 1 / 26 & & \text { Fuel Cells (AB) } \\ 2 / 2 & & \text { Fuel Cells (AB) } \\ 2 / 9 & & \text { Wind Energy (CWS) } \\ 2 / 16 & & \text { Wind Energy (CWS) } \\ 2 / 23 & & \text { Geothermal Energy (AB) } \\ 3 / 1 & & \text { Geothermal Energy (AB) } \\ 3 / 8 & & \text { Spring Break } \\ 3 / 15 & \text { Ocean Energy (CWS) } \\ 3 / 22 & \text { Ocean Energy (CWS) } \\ 3 / 29 & \text { Nuclear Energy (CWS) } \\ 4 / 5 & \text { Nuclear Energy (CWS) } \\ 4 / 12 & \text { Solar Energy (AB) } \\ 4 / 19 & \text { Solar Energy (AB) } \\ 4 / 26 & \text { Biomass Energy (AB) }\end{array}$




\section{Attachment 2 Syllabus for Spring 2004 (continued)}

\section{$\underline{\text { Projects }}$}

1. Essay on the Pros and Cons of Alternative/Renewable Energy Systems

2. Design of a Fuel Cell System

3. Design of a Wind Farm

4. Design of a Geothermal System

5. Design of a Wave Energy System

6. Design of a Solar Energy System

Projects \#1 and \#4 will be done on an individual basis. The remaining projects will be done in groups of two as assigned by the instructors.

\section{Grading}

All six projects will count equally in the course grade. We grade on the basis of a distribution. That is, we graph the class's numerical scores and draw the grade divisions based on how students group themselves. We use a straight scale to guide us in setting these grade divisions.

\section{Assignment Due Dates \\ (Tentative)}

\begin{tabular}{|c|c|}
\hline Assignment & Due Date \\
\hline Project \#1 & $2 / 9 / 04$ \\
\hline Project \#2 & $2 / 23 / 04$ \\
\hline Project \#3 & $3 / 15 / 04$ \\
\hline Project \#4 & $3 / 29 / 04$ \\
\hline Project \#5 & $4 / 12 / 04$ \\
\hline Project \#6 & $5 / 6 / 04$ \\
\hline
\end{tabular}




\title{
Attachment 3 Project Statement for Wind Farm Project
}

\author{
ME 417 \\ Design of Alternative Energy Systems
}

\section{Project 3 Design of a Wind Power System Due Friday, March 18, 2005}

The Air In Motion (AIM) Administration for the state of Iowa has hired the engineering firm of Bénard and Somerton (aka BS Engineering) to provide preliminary designs for wind power systems in the state. Two associates of the firm have been assigned to investigate two different sites in the state. Each associate will perform the design analysis for a single site. The team will use the Iowa Energy Center Wind Turbine Output Calculator located at

http://www.energy.iastate.edu/renewable/wind/assesment/

The two sites are to be in different counties in the state of Iowa. A design analysis should be done at each site for two power systems. One system should have a operating of power 1500 $\mathrm{kW}$, while the other system should have an operating power of $65 \mathrm{~kW}$.

For each site and power system, the design team will undertake a design study to determine

- turbine type

- the optimal tower height

The following turbines shall be considered for the two power systems:

$1500 \mathrm{~kW}$ Power System

Nordtank 1500/64 (rotor diameter of $60 \mathrm{~m}$ )

GE Wind 1.5s (rotor diameter of $77 \mathrm{~m}$ )

NEG Micon NM72C/1500 (rotor diameter of $82 \mathrm{~m}$ )

$\underline{65 \mathrm{~kW} \text { Power System }}$

Vestas V15 $65 \mathrm{~kW}$ (rotor diameter of $18 \mathrm{~m}$ )

Nordtank 65 (rotor diameter of $20 \mathrm{~m}$ )

Windmatic $15 \mathrm{~S}$ (rotor diameter of $11 \mathrm{~m}$ )

The objective function used in the design study will be the predicted cost of the electricity in $\$ / \mathrm{kW} \cdot \mathrm{hr}$. The team will want to compare the results of the design studies at the two sites.

The following parameter values should be used in the design analysis:

Site: High Exposed Unobstructed Crop Land

Loss Factor: $12 \%$

Maximum Rotor Height: 100 m

Interest Rate: 8\%

System Life: 30 years 


\section{Attachment 3 Project Statement for Wind Farm Project (continued)}

In determination the objective function, the following factors must be included:

Cost of Tower: $(0.1 \mathrm{x} \text { rotor diameter in } \mathrm{m})^{2} \mathrm{x}(0.3 \mathrm{x}$ tower height in $\mathrm{m}) \mathrm{x} 500$

Cost of Generator: $35 \mathrm{x}$ (turbine power in $\mathrm{kW}) \div(\mathrm{A} / \mathrm{P}, \mathrm{i}, \mathrm{N})$

Cost of Blades and Rotor: $6 \mathrm{x}$ (rotor diameter in $\mathrm{m})^{3}$

The cost of the power produced in $\$ / \mathrm{kWh}$ is then

$$
\text { Power Cost }=(\text { capital costs }) \times(\mathrm{A} / \mathrm{P}, \mathrm{i}, \mathrm{N}) \div(\text { annual energy produced })
$$

where

$$
(\mathrm{A} / \mathrm{P}, \mathrm{i}, \mathrm{N})=\frac{\mathrm{i}(1+\mathrm{i})^{\mathrm{N}}}{(1+\mathrm{i})^{\mathrm{N}}-1}
$$

The team is required to submit a technical memo that documents their work. It is suggested that this documentation might include graphs of power cost versus tower height for all six turbines at both sites. The memo should also include a final design decision for each power system at each site. 
Attachment 3 Project Statement for Wind Farm Project (continued)

ME 417

Design of Alternative Energy Systems

Project Grade Evaluation

Project 3 Design of a Wind Power System

Student Names:

\begin{tabular}{|c|c|c|c|c|c|}
\hline Topic & $\begin{array}{c}\text { Assigned } \\
\text { Score } \\
\text { Site \#1 } \\
\mathbf{6 5 ~ k W}\end{array}$ & $\begin{array}{c}\text { Assigned } \\
\text { Score } \\
\text { Site \#1 } \\
\mathbf{1 . 5} \mathbf{~ M W}\end{array}$ & $\begin{array}{c}\text { Assigned } \\
\text { Score } \\
\text { Site \#2 } \\
\mathbf{6 5 ~ k W}\end{array}$ & $\begin{array}{c}\text { Assigned } \\
\text { Score } \\
\text { Site \#2 } \\
\mathbf{1 . 5} \mathbf{~ M W}\end{array}$ & $\begin{array}{c}\text { Maximum } \\
\text { Score }\end{array}$ \\
\hline $\begin{array}{c}\text { Determination of } \\
\text { Tower Height }\end{array}$ & & & & & 40 \\
\hline $\begin{array}{c}\text { Determination of } \\
\text { Turbine Type }\end{array}$ & & & & & 40 \\
\hline \hline $\begin{array}{c}\text { Comparison of Sites } \\
\text { Comparison of Power } \\
\text { Systems }\end{array}$ & & & & 5 \\
\hline Quality & & & & 10 \\
\hline Total & & & & 100 \\
\hline
\end{tabular}




\title{
Attachment 4 Project Statement for Oscillating Water Column Project
}

\author{
ME 417 \\ Design of Alternative Energy Systems

\section{Project 5 Design of an Oscillating Water Column Power System Due Friday, April 16, 2004}

The U.S. Senate subcommittee on coastal energy resources has hired the engineering firm of Bénard and Somerton (aka BS Engineering) to provide a preliminary design for an oscillating water column system power within the territory of the United States. Two or three associates of the firm have been assigned to investigate two or three different sites in the United States. Each associate will perform the design analysis for a single site. The following sites have been targeted for this study.

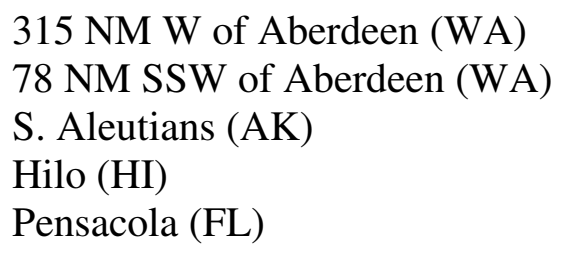

For each site, the design team will undertake a design study to determine

- the optimal chamber height (within $0.5 \mathrm{~m}$ )

- the optimal chamber diameter (within $0.5 \mathrm{~m}$ )

The objective function used in the design study will be the predicted cost of the electricity in $\$ / \mathrm{kW} \cdot \mathrm{hr}$, under the constraint that the system power output will be $10 \mathrm{~kW}$. The team will want to compare the results of the design studies at the different sites. The design team should perform a design study for each of four different months at each site.

The following parameter values should be used in the design analysis:

Interest Rate: $12 \%$

Turbine Life: 20 years

A MATLAB computer program, OWCPower.p, has been provided to assist you in the calculations. The user's guide for the program is attached.

To get started the student needs to choose a site and a month. Using the OWCPower.p program, the student should start at a chamber height (say 5 meters) and a chamber diameter (say 10 meters), and then change the chamber diameter until a power output of $10 \mathrm{~kW}$ is achieved. The economic analysis should then be conducted. The chamber height should then be changed and the process repeated until the chamber diameter/height combination is obtained that minimizes the power cost. The month is then changed and the search for an optimum chamber diameter/height combination for the new month is conducted. This optimization search is done 


\section{Attachment 4 Project Statement for Oscillating Water Column Project (continued)}

for any four months. Using the results for these four months, the student needs to choose an final chamber diameter/height combination based on minimum power cost and viability. The OWCPower.p program should then be run with this final design for each month of the year, which would produce a graph of Power Cost vs. Month. Appropriate documentation (tables and graphs) for the optimization and design study must be provided in the report that will support the design decision. The documentation should include the data of the directional walk optimization, a graph of power output vs. chamber diameter, and a graph of power cost vs. chamber volume.

\section{User Instructions for OWCPower.p Copyright 2004 by Karena Heikkila and Craig W. Somerton}

The program OWCPower.p is a MATLAB pseudo code that performs the operational and economic analysis for an oscillating water column power system at five different locations. The program OWCPower.p must be run within MATLAB. With MATLAB open and the path set correctly to access the directory that contains the OWCPower.p file, the program may be run by typing at the MATLAB prompt:

EDU» OWCPower

and pressing the Enter key. At this point the program will begin to prompt the user for operating information about the oscillating water column system. Once the chamber height and diameter is specified, the user is asked to identify a site and a month for the calculations. Results for the OWC system are then provided. If an economic analysis is desired, the user must input the interest rate and the OWC life.

Limitations: This program has been written as an in-house engineering code, so it is assumed the user is well versed in fan systems and their calculations, hence there is very little error checking within the program. 
Attachment 4 Project Statement for Oscillating Water Column Project (continued)

ME 417

Design of Alternative Energy Systems

Project Grade Evaluation

Project 5 Design of an Oscillating Water Column Power System

Student Names:

\begin{tabular}{|c|c|c|c|}
\hline Topic & $\begin{array}{c}\text { Assigned } \\
\text { Score } \\
\text { Site \#1 }\end{array}$ & $\begin{array}{c}\text { Assigned } \\
\text { Score } \\
\text { Site \#2 }\end{array}$ & $\begin{array}{c}\text { Maximum } \\
\text { Score }\end{array}$ \\
\hline Month 1 Optimization & & & 10 \\
\hline Month 2 Optimization & & 10 \\
\hline Month 3 Optimization & & 10 \\
\hline Month 4 Optimization & & 10 \\
\hline Graph of Power Output vs Chamber \\
Diameter & & 10 \\
\hline Graph of Power Cost vs Chamber \\
Volume & & 10 \\
\hline \hline Final Design Recommendation & & 10 \\
\hline \hline Graph of Power Cost vs Month & & 10 \\
\hline \hline Comparison of Sites & & 100 \\
\hline Quality & & \\
\hline Total & & 10 \\
\hline
\end{tabular}

